\title{
Overlapping of pedogenesis and meteoric diagenesis in distal alluvial and shallow lacustrine deposits in the Madrid Miocene Basin, Spain
}

\author{
$\mathrm{M}^{\mathrm{a}}$.A. Bustillo ${ }^{\mathrm{a}, *}$, A.M $^{\mathrm{a}}$. Alonso-Zarza ${ }^{\mathrm{b}}$ \\ a Dpto. de Geología, Museo Nacional de Ciencias Naturales, CSIC, José Gutiérrez Abascal 2, Madrid 28006, Spain \\ ${ }^{\mathrm{b}}$ Dpto. de Petrología y Geoquímica, Facultad de Ciencias Geológicas, UCM, Madrid 28014, Spain
}

\begin{abstract}
The Miocene distal alluvial fan and palustrine deposits of the Madrid Basin (Paracuellos de Jarama area) were examined to establish the sequence of its pedogenic-diagenetic processes and the main factors controlling them. In this area the diagenetic processes operated not only on carbonates, as commonly studied, but also in high magnesium clays and opaline cherts. This paper provides a dynamic model for saline-alkaline lake margins that complements the existing freshwater palustrine model. Three sections (BER, PEL and UPC) containing limestones, sepiolite, dolostones and opaline cherts were examined; these represent the entire transition from alluvial fan deposit to lake environment. The alluvial fan deposits (PEL section) show the most complex sequence of processes. After a weak edaphic imprint, the primary mudstone and siltstones are affected by silicification (opaline levels formed mainly by selective replacement of sepiolites) and later dolomitization. Several types of dolomite are present, rounded crystals, spherules and globular bodies being the most characteristic. In the ponds situated at the foot of the alluvial fans or in interfan areas, sepiolite precipitated within free water bodies (BER section) and an intense pedogenesis led to the formation of palustrine sepiolite deposits. Later, the intense silicification of the sepiolite produced lenticular opaline levels that were locally transformed to quartz by aging.

In the shallow lakes (UPC section), palustrine limestones and sepiolite were deposited. The carbonates are partially affected by silicification, the sepiolite becoming completely silicified. The opaline levels clearly preserve the structure of the limestones and sepiolite host rocks. All the opaline levels show local aging processes.

The silicification processes were different in the three settings due to the interplay of groundwater with sedimentary environments and facies. In the distal alluvial fan sediments of the PEL section, the initial host rock affected by silicification is not preserved due to the later dolomitization that erased both it and its textures. The silicification environment was therefore not easy to determine. In the BER and UPC section, the main silicification took place in groundwater-influenced environments but evidence was seen of cements and silicifications in vadose environments. In all study settings, the overlapping of pedogenic, vadose and groundwater processes was controlled by changes in the position of the water table. Four stages were concluded to explain the transformation from the primary deposits to the later dolomitization process and the formation of vadose cements. The majority of the silicifications seen occurred as responses to changes in the water table position linked to the aggradation of this closed basin.

In all the studied environments, the sepiolite deposits were preferentially silicified; their fibrous structure and high absorption capacity helping to retain interstitial fluids. Moreover sepiolite and opal are stable under relatively similar geochemical conditions
\end{abstract}


in arid environments. The dissolution of the sepiolite caused an increase in silica in the interstitial fluids, favouring silicification and ruling out the need of a biogenic source. The replacement of limestones by silica is usually driven by variations in $\mathrm{pH}$ and salinity, which are very common in surface environments such as shallow lakes and soils.

Keywords: Silcretes; Vadose environment; Groundwater; Dolomitization; Palustrine sediments; Sepiolite

\section{Introduction}

The distal alluvial fan areas of hydrologically closed basins are subject to a complex set of sedimentary and diagenetic processes as a result of changes in the position of the water table and in the geochemistry of groundwater. The mixing of groundwater of meteoric composition with more saline water from any surrounding closed lacustrine areas, the level of rock-water interaction and variation in the climate, render such alluvial fans uniquely suited to the study of the relationships between pedogenic and diagenetic processes in terrestrial environments. More- over, in alluvial fans, small rises in the water table favour the formation of shallow lakes, and slight fluctuations can result in the overlapping of sedimentary, pedogenic and early diagenetic processes whose interpretation is important in understanding the dynamics of these terrestrial systems. Much of the work performed in these environments has centred on the transition between pedogenic environments and palustrine carbonates, focusing mainly on the formation and diagenesis of carbonates (Freytet and Plaziat, 1982; Alonso-Zarza, 2003). Less is known about deposits including not just carbonates but also magnesium clays and opaline cherts.
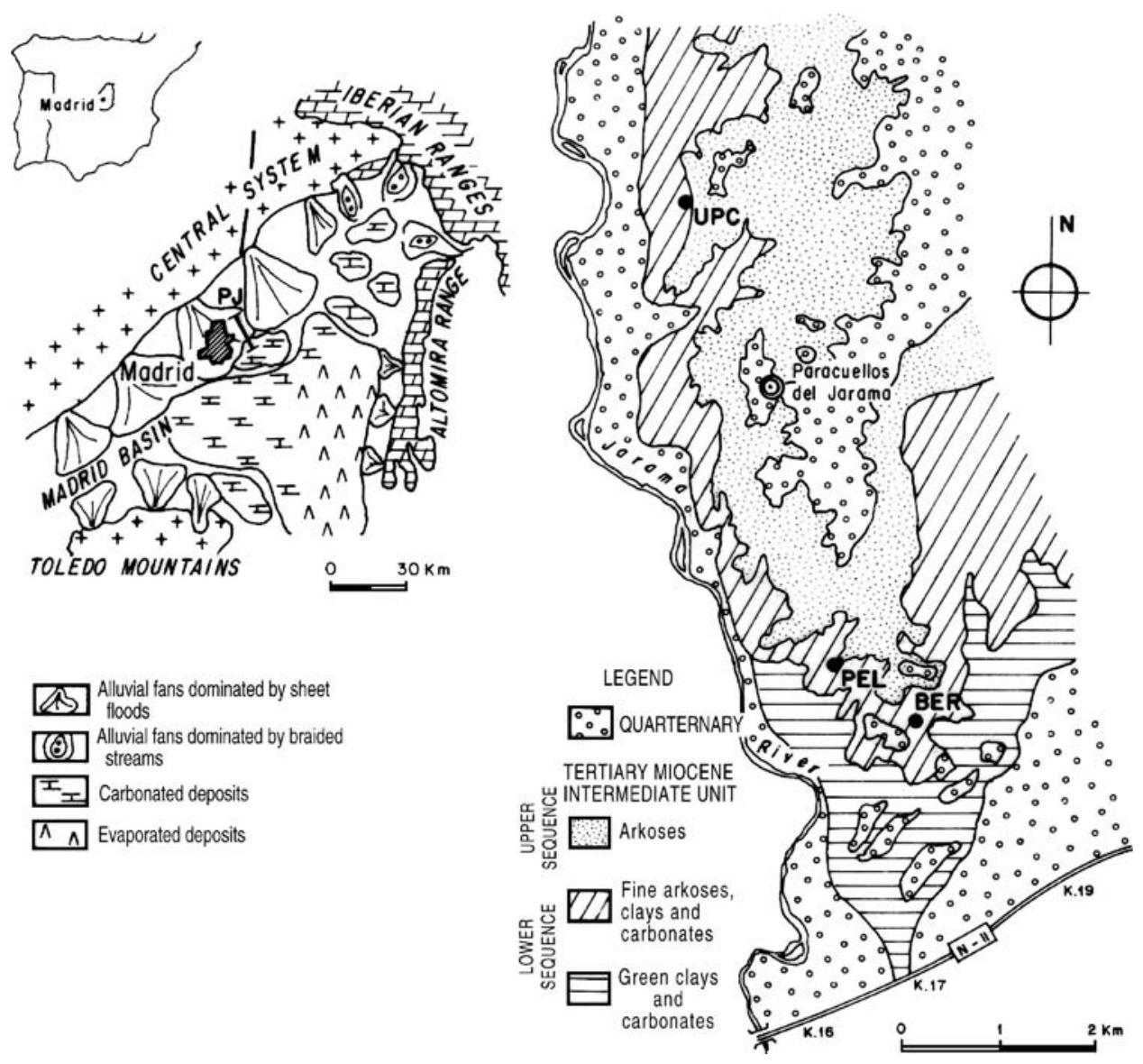

Fig. 1. Location of the study area (Paracuellos de Jarama, PJ) in a palaeogeographic sketch of the Madrid Basin and map showing the situation of the 3 studied sections (one incorporate two profiles) and the cartography of the main Miocene units. 
This paper reports an analysis of distal alluvial deposits and palustrine carbonates and sepiolite within the Miocene deposits of the Madrid Basin. All these sediments underwent pedogenic and diagenetic processes that allowed the formation of pedogenic carbonates and sepiolite, as well as their silicification and dolomitization. The aim of this study was to determine how these deposits formed in order to establish the sequence of the pedogenic-early diagenetic processes that occurred in these environments, and to determine the main factors controlling them. The study area is unique because of the excellent outcrop conditions and the fact that the transition from the different environments occurs in a relatively narrow area, so its study can be made more clearly. The study carried on this area can be used to better understand the sequence of pedogenic-diagenetic processes along the transition between alluvial fan and lacustrine environments in other areas of the basin and in other closed basins.

\section{Geological setting}

The sediments analysed in this paper are part of the Miocene deposits in the north of the Madrid Basin, central Spain (Fig. 1). This basin and its sedimentary infilling have been studied intensively over the last twenty years (see for example Calvo et al., 1989; Alonso-Zarza et al., 2004). Continental sediments ranging in age from Palaeogene to Pliocene fill the basin. Palaeogene rocks only outcrop at the margins of the basin; most are Neogene in age. The basin's Miocene deposits have been divided into three units: the Lower, Intermediate and Upper Miocene Units (Junco and Calvo, 1984). In some areas these are overlain by Pliocene clastics and carbonates (Fig. 2). The material

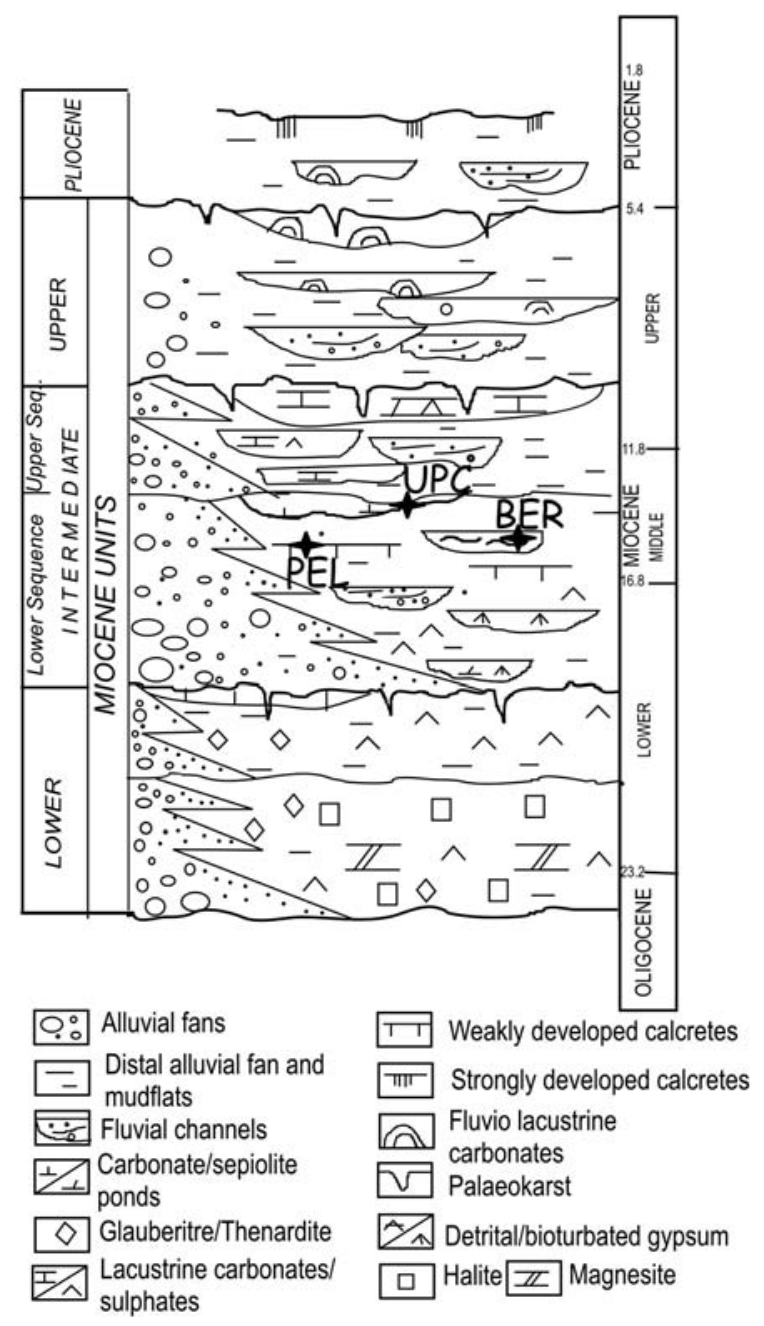

Fig. 2. Stratigraphy of the Madrid Basin, showing the main Neogene units and the studied sections (PER, BER and UPC). 
analysed in this paper came from the Intermediate Miocene Unit, which in this northern part of the basin consists of a lower and upper sequence (Alonso et al., 1986) (Fig. 2). The lower sequence, middle to upper Aragonian in age, has a maximum thickness of $50 \mathrm{~m}$ and comprises a complex succession from medial alluvial fan facies in the northernmost area to lake deposits in the south. The alluvial fan sediments consist of coarse arkosic sands, fine loose gravels and brown clays, usually organized in fining-upward sequences. Towards the south, fine arkoses and brown clays are the dominant lithofacies. The clays are illite, smectite and also sepiolite (Doval et al., 1985). Calcretes and dolocretes are commonly intercalated within clastic deposits and are the most characteristic lithofacies of the transition between the arkosic alluvial fans and the lake environment (Calvo et al., 1989). The calcretes, dolocretes and clays commonly contain lenticular levels and nodules of opaline cherts. These distal fan deposits grade to lake margin facies composed of green $\mathrm{Mg}$-smectite rich clays, palustrine nodular dolostones, and sepiolite beds. The upper sequence, upper Aragonian to Vallesian in age, consists of $60 \mathrm{~m}$ of loose gravel and coarse arkosic sands with little clay (Fig. 2), indicating the installation of more proximal fan environments (Alonso et al., 1986). Calcretes and dolocretes are not present in the upper sequence of this area and sepiolite and chert are scarce.

\section{Methods}

Three sections containing carbonates, sepiolite and opaline cherts were selected to cover a wide spectrum of transformation related to pedogenesis and early diagenesis in terrestrial settings. The four main profiles were studied (Fig. 3) because they illustrate the complexity of these processes in closely related sedimentary environments. One represented distal alluvial environments (the PEL section), in another (the BER section) sepiolite was deposited in isolated ponds, and two profiles (in the UPC section) represented shallow lake environments.

Thin sections of samples were studied by transmission light microscopy. Their mineralogy was determined using a Philips XDR system (PW 1710) and monochromated $\mathrm{CuK} \alpha$ radiation. Scanning electron microscopy (SEM) was performed with a FEI QUANTA 200 apparatus working at $30 \mathrm{kV}$ and at a distance of $10 \mathrm{~mm}$, using secondary electron and backscattering detectors. The microscope had two X-ray detection systems - an energy dispersion system (EDS) and a wave dispersion system (WDS) - usable either simultaneously or

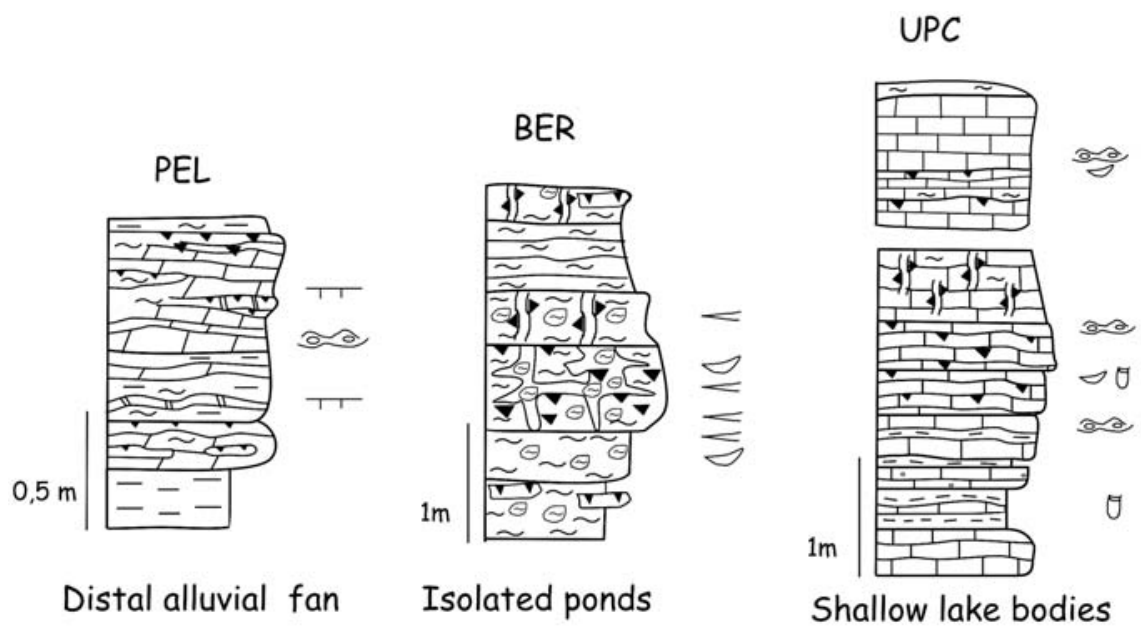

\begin{tabular}{|c|c|c|c|c|c|}
\hline 5 & Limestones & $\nabla \nabla$ & Opal and Chert & $T$ & Incipient calcretes \\
\hline H & Dolostones & $0_{0}$ & Sand & $\approx$ & Alveolar structure \\
\hline IIII & Calcrete laminae & $\Theta_{\theta}$ & Sepiolite intraclasts & $\approx$ & Desiccation cracks \\
\hline- & Mudstones & 5 & Brecciation & $\circlearrowright$ & Vadose cements \\
\hline$\approx$ & Sepiolite & $\iint$ & Prismatic structure & 0 & Bioturbation \\
\hline
\end{tabular}

Fig. 3. Logs of the study sections. 
alternatively. Stable isotope analyses were performed on powdered samples (following reaction with 100\% phosphoric acid) using a SIRA analyser.

\section{Types of profiles and selected sections}

\subsection{The BER section: transformations in sepiolite pond deposits}

\subsubsection{Profile and macromorphology}

The BER section is located at the southernmost part of the study area, where it forms part of a complex sequence of very shallow lacustrine deposits including green and brown mudstones, carbonate lenses and sepiolite deposits (Alonso et al., 1986). The studied profile was $3.45 \mathrm{~m}$ thick (Figs. 3 and 4A). From the base to the top it includes:

1) $1 \mathrm{~m}$ of massive and pale brown sepiolite with opaline nodules surrounded by oriented clays. The nodules vary in size from about 3 to $30 \mathrm{~cm}$ in diameter (Fig. 4B).

2) $0.4 \mathrm{~m}$ of brecciated sepiolite.

3) $0.7 \mathrm{~m}$ of sepiolite, intensively silicified to form a lenticular bed of opaline chert about $4 \mathrm{~m}$ wide. This bed includes angular and rounded silicified sepiolite intraclasts, horizontal desiccation planes, and vertical and horizontal channels (from 1 to $30 \mathrm{~cm}$ ) probably enlarged root cavities (Fig. 4C). The intraclasts are included in the silicified sepiolite groundmass and fill the different cavities. These features are very similar to those commonly recognised in palustrine carbonates (Freytet and Verrecchia, 2002; Alonso-Zarza, 2003), except that here the host rock is mostly sepiolite.

4) $0.35 \mathrm{~m}$ of silicified sepiolite showing a prismatic structure due to root penetration. The silicification formed opaline cherts, the distribution of which follows the vertical trend of the roots.

5) $0.70 \mathrm{~m}$ of an irregularly laminated bed of sepiolite.

6) $0.30 \mathrm{~m}$ of a level similar to 4 , where many nodules of opaline cherts show a vertical trend following rootrelated structures.

\subsubsection{Mineralogy and petrology}

The silicified host rock is mostly formed by sepiolite. Calcite and dolomite are only present in small quantities (less than 5\%). In the opaline cherts the dominant mineral is opal CT, making up about 70-85\% (some opal A may be masked within the opal CT peak). Quartz makes up about $10 \%$; the rest is composed of sepiolite relics. The sepiolite host rock located close to the nodules is more compact and includes up to $30 \%$ opal CT.
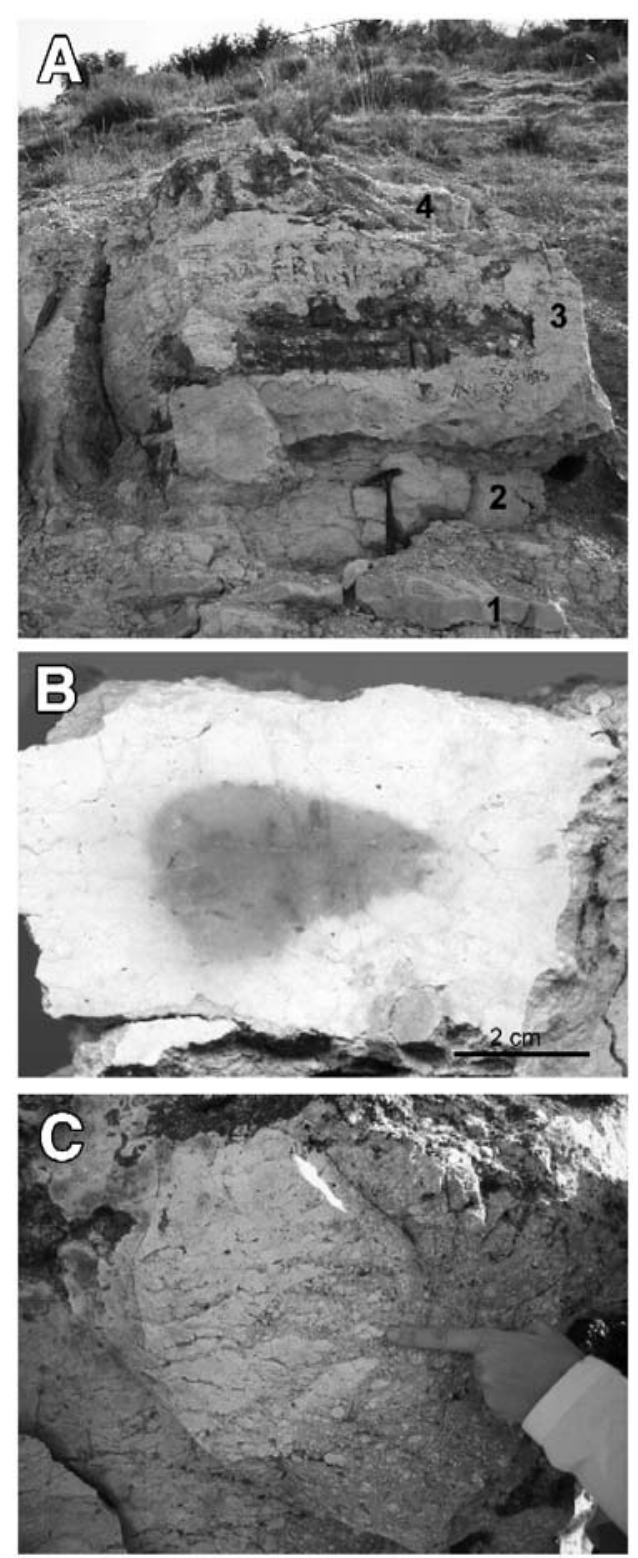

Fig. 4. BER section. (A) Parts 1, 2, 3 and 4. A later silica skin of opal and several graffitis mask some parts of the outcrop. (B) Small opaline nodule from Part 1 . The pseudomorphic silicification completely preserved the structure of the sepiolite host rock. (C) Close-up of the opaline chert level (part 3) with palustrine features: intraclasts, brecciation and horizontal desiccation cracks filled by intraclasts and granules. Right: a large vertical channel filled by sepiolite intraclasts.

The sepiolite groundmass shows a brecciated texture formed by intraclasts. These intraclasts vary in size from $<1 \mathrm{~mm}$ to a few centimetres. The largest are very angular and irregular (intraclasts) and the smaller ones more rounded (granules). Both granules and intraclasts are coated by thin films of clay (cutans). In some places granules are the result of 
desiccation to form circumgranular cracks around them. Under thin section microscopy the sepiolite shows strong striated birefringence (crossed nicols). The sepiolite host rock close to the opaline cherts (transition zone) shows a diffuse impregnation of silica that makes it more compact; under optical microscopy it is more yellow and shows stronger relief.
The intense silicification in the middle part of the profile (zone 3) (Fig. 4A) produced opals that show many textures and structures of palustrine deposits. The structure of the sepiolite (intraclasts and granules, cracks, channels and cavities) (Fig. 4B and C), is easily visible in the opaline cherts. In plane polarized light the opals show, intraclasts and granules similar to those of the sepiolite (Fig. 5A), and also large glaebules
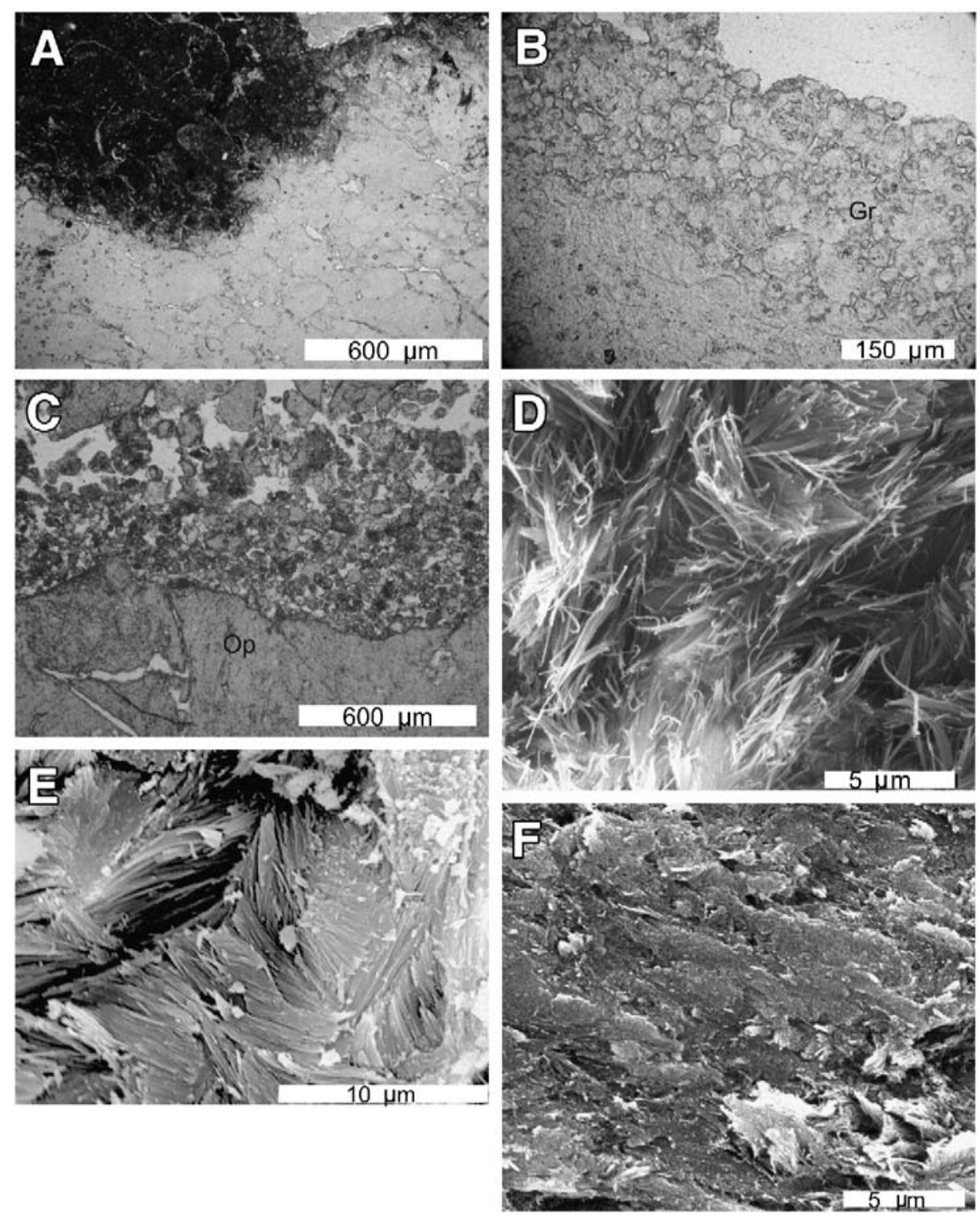

Fig. 5. Microscopic features of the BER section. (A) Sepiolite host rock (upper dark part) and the opal resulting from silicification (lower lighter part). The granular texture and cracks are entirely preserved in the opal. Parallel plane light. (B) Void in the opaline rock. The margin of the opaline rock shows grainification (Gr). Parallel plane light. (C) A crack (upper part) in the opaline rock (Op) filled by intraclasts and small granules formed by reworking and internal sedimentation. Parallel plane light. (D) SEM photomicrograph of the sepiolite host rock. The fibres are thin and loose. (E) SEM photomicrograph of the transition zone between the sepiolite host rock and the opaline rock resulting from silicification. The fibres are thicker and have joined, forming platelets. (F) SEM photomicrograph of the opaline rock. Although more compact, some of the initial fibrous structure of the sepiolite host rock is still visible. 
containing other small granules, that sometimes show an exterior rim. Under crossed nícoles the opal has striated birefringence that is inherited of the sepiolitic host rock. Many features indicate the pseudomorphic replacement of the sepiolite by silica. Quartz appears as a consequence of cementation and aging (Bustillo, 1982). The cementation of the cavities was initially undertaken by microcrystalline or fibrous opal (lussatite), or length-fast chalcedony, and sometimes by later length-slow chalcedony or megaquartz. In some pores in the margin of the void the homogeneous opal break off in small grains (grainification) (Fig. 5B). In others, intraclasts and granules form the first infill of the cavities, resembling an internal sediment (Fig. 5C). The grainification and the internal sedimentation occurred in the vadose environment as they did not fill completely the cavities and are also followed by vadose cement. The transition from sepiolite to opaline chert was observed by SEM. The sepiolite fibres of the host rock appear thin and delicate (Fig. 5D) but advancing silicification led to their sticking to each other, initially forming platelets (Fig. 5E) and finally producing a compact opaline network (Fig. 5F). Sometimes the fibres appear to be composed of aligned, minute silica microspheres (200$300 \mathrm{~nm}$ ). In the transition zone between the sepiolite and the opaline chert, no precise chemical quantitative analysis of the fibres was possible because they were very thin and the electron beam probed the opal matrix at the same time. However, the ED analysis showed the fibres of this transition zone to be enriched in silica and to have less $\mathrm{Mg}$ than the sepiolite host rock. In the opaline chert, the fibres were composed totally of silica or had only traces of $\mathrm{Mg}$.

\subsection{The PEL section: transformations on distal alluvial deposits}

\subsubsection{Profile and macromorphology}

This profile is located towards the top of the lower sequence of the Miocene Intermediate Unit (Fig. 2) and is developed on the distal facies of the arkosic alluvial fans (Alonso et al., 1986). It is $1.05 \mathrm{~m}$ thick and formed by three horizons. The lower (18 cm thick) and upper $(55 \mathrm{~cm})$ are hard, the intermediate is soft. The harder horizons are mostly composed of opaline cherts (Fig. 3). These opaline cherts - lenticular beds with a diffuse inner banded structure - are beige, brown or grey, and range from vitreous to crystalline in appearance. These properties reflect the complex mineralogy and texture of these materials. In the outer part of the lenticular beds, the opaline chert loses its brightness and compactness and shows adhesion via moisture (as for sepiolite). The intermediate bed was $30 \mathrm{~cm}$ thick, massive, and mostly dolomitic with interbedded brown clays. The contacts between the horizons are transitional and contain dolomitic opaline cherts.

\subsubsection{Mineralogy and petrology}

The clays underlying this profile are mostly composed of smectites with illite and relics of quartz and feldspars. Within the profile, minor sepiolite (up to $10 \%$ ) is associated with the opaline cherts, with inconsiderable amounts of smectites and occasionally palygorskite. Gypsum moulds and dolomite pseudomorphs after gypsum are scarce.

The carbonates formed lenticular levels of dolostones. Calcite is rare and occurs as thin micritic filaments or alveolar-septal structures indicating microbial activity (Wright, 1986). Some micritic peloids (rounded micritic grains) occur locally. The dolomite crystals have different sizes and textures. Millimetric dolomicrite levels are rare and irregularly distributed. Coarser dolomite mosaics are common, formed by larger crystals (20 to $100 \mu \mathrm{m}$ ) with varied morphology (rhombohedral, anhedral and rounded) and, spheroidal aggregates (Fig. 6A) sometimes with a dark or hollow centre. Locally, clay films can be observed between the crystals. On occasion, the dolomite crystals tend to follow the micrite filaments. Some associations of minute crystals form globular bodies or spherules, the latter showing a fibrous-radial texture. At some points the globular bodies show dolomicritic nuclei. All the dolomite crystals are also found within the opaline cherts (Fig. 6B). Under SEM, the rounded dolomite crystals were small (about 20-40 $\mu \mathrm{m}$ ) (Fig. 6C) and were different to the dolomite spherules composed of coalesced rhombohedral subunits (Fig. 6D). Clay fibres sometimes coated the small rhombohedral crystals, possibly sepiolite, on which the nucleation of opal lepispheres was observed (Fig. 6E). Sometimes the spherules were composed of a hollow core enveloped by a dolomite cortex (Fig. 6F). In other cases the rhombohedral subunits were oriented following the radii of the spherulites (Fig. 6G). The larger globular bodies are sometimes coated by a thick argillaceous film easily observed under SEM (Fig. 6G). WDS analysis of the fibrous spherulites showed a progressive increase in the $\mathrm{Mg} / \mathrm{Ca}$ ratio from the core of the spherules towards the outer regions (Fig. 6H).

The opaline cherts consist mostly of opal CT, with some areas enriched in quartz and probably small amounts of opal A. These cherts show different textures and structures along the profile and include charophyte relics and unidentified biosiliceous components (pos- 

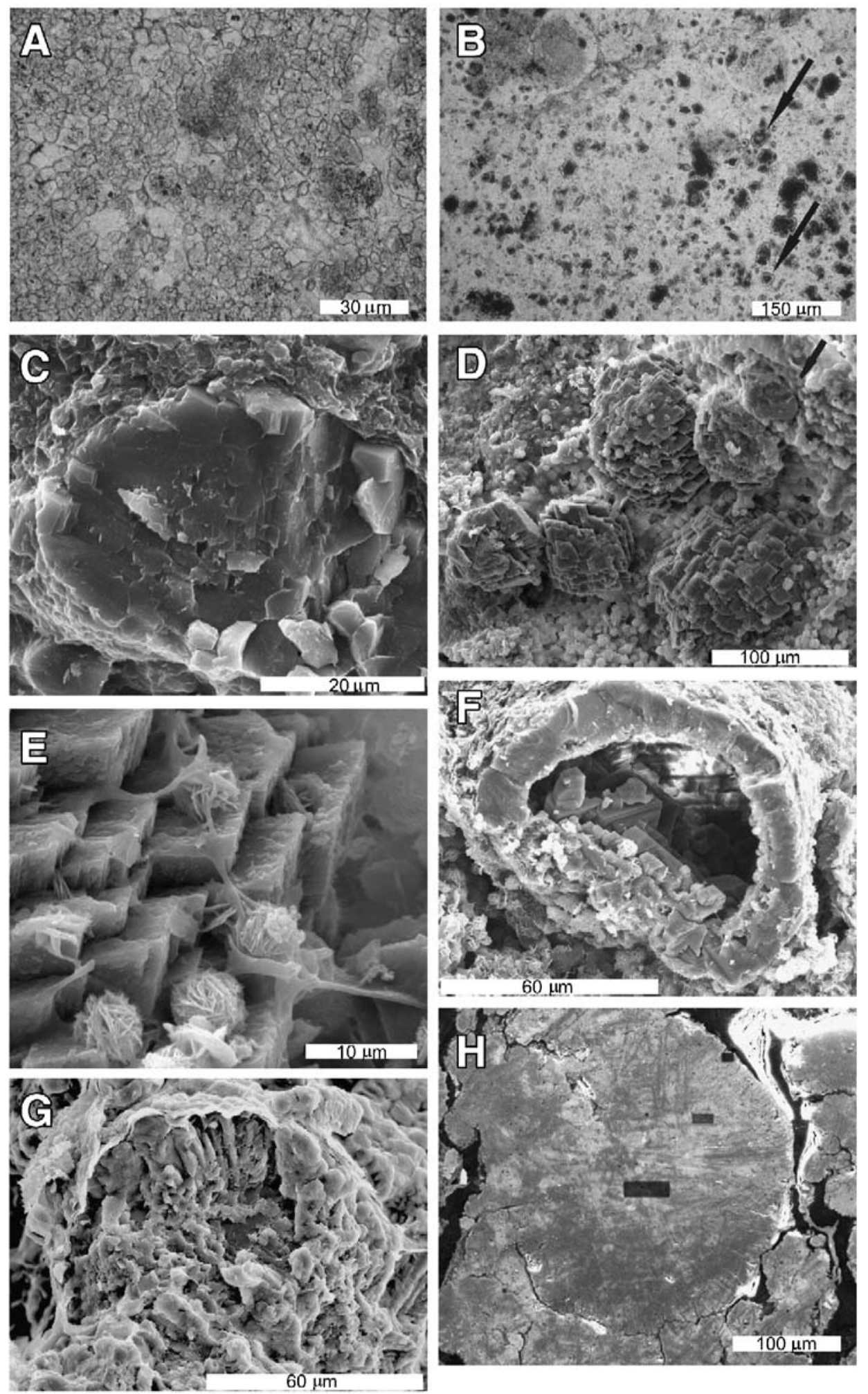
sibly silicified plant fragments and phytoliths). The opaline cherts have intraclastic, granular and glaebular textures (in sense of Summerfield, 1983). In the latter, the glaebules show concentric silica envelopes. The opal shows striated birefringence, but also isotropic opal occurs. Two isotropic opal types can be distinguished. Type I shows strong relief and has a dark colour under plane polarized light; occasionally it passes gradually to striated opal. Type II shows a less marked relief and includes relics of micritic carbonates. Both types of isotropic opal partially age to microcrystalline quartz mosaics (Fig. 7A and B). Quartz also occurs as cement, filling the pores as length-fast chalcedony and mesoand macrocrystalline mosaics. At some points, all the different types of dolomite crystals described above are superimposed on the opaline cherts (Figs. 6B, 7A and $\mathrm{B})$.

Under the SEM, the striated opal had a fibrous structure, very similar to that of fibrous magnesian clays (e.g., sepiolite), but the opal fibres were usually shorter and wider that those normally associated with such clays. This structure may have formed when the opal was nucleated on fibrous clay, in this case sepiolite. At some points the fibres of sepiolite were the nucleation sites for small opal lepispheres (Fig. 7C). Similar lepispheres growing from the fibre bundles were previously interpreted as sepiolite by Gehring et al. (1995), but in the studied case are only of silica. Lepispheres of different size $(3-20 \mu \mathrm{m})$ were common in the different types of void.

\subsection{UPC section: transformations of shallow lacus- trine carbonate deposits}

\subsubsection{Profiles and macromorphology}

The profiles studied in the UPC section (Fig. 3) are located in two beds of palustrine carbonates deposited at the top of the lower sequence of the Intermediate Unit. These profiles are separated by $3 \mathrm{~m}$ of fine clastic deposits.

The lower profile is $2.7 \mathrm{~m}$ thick and consists of a lower, $1.1 \mathrm{~m}$ thick portion of sandy limestones intercalated with brown mudstones. These limestones show desiccation cracks and bioturbation tubes. The middle portion consists of $0.8 \mathrm{~m}$ of irregularly laminated limestones with insect traces; they are intensively silicified. The upper part $(0.8 \mathrm{~m})$ is formed by limestones with vertical prismatic structure and sepiolite. It is also silicified to form opaline cherts.

The upper profile is $1.2 \mathrm{~m}$ thick and consists of irregularly banded limestones with desiccation cracks that, at the top, include $10 \mathrm{~cm}$ of brecciated limestones with sepiolite and opaline chert. Silicification occurs mostly in the upper part of the profile.

\subsubsection{Mineralogy and petrography}

The limestones are formed by calcite (dolomite is totally absent) and clays (mostly sepiolite with small amounts of illite and palygorskite); these clays make up $20 \%$ of the rock. Quartz and opal are present in varying amounts, from mere traces to $90 \%$, depending on the degree of silicification.

Texturally the limestones consist of micritic grains, either rounded (peloids) or angular (intraclasts). Ostracod and gastropod shells are scarce. These limestones formed by the breakage of the lacustrine micritic muds by both desiccation and root bioturbation (AlonsoZarza, 2003). This process is known as grainification and results in the formation of grainstones or syngenetic granular limestones from an initial micritic limestone (Freytet and Plaziat, 1982; Mazullo and Birdwell, 1989). Alveolar septal structures (Wright, 1986) are present within the micrite and within the pores. These, together with the common occurrence of thin (1$10 \mathrm{~mm}$ ) calcified root-mats (Wright et al., 1988) and root tubes, are proofs of the former activity of roots throughout the profile. Biogenic influence in the formation of these limestones is also shown by the presence of silicified bioturbations, fenestral structures and calcified filaments. The latter are seen in the micrite associated with tubes and also form some of the coatings of both intraclasts and peloids, as commonly described for palustrine environments (Alonso-Zarza et al., 1992). At the base of the profiles silicification is local. The silica is present as small lepispheres that either cement pores or replace local micrite crystals. At some points, the lepispheres nucleate on sepiolite fibres that coat the calcite crystals.

Fig. 6. Microscopic features of the dolomite in the PEL section. (A) Dolostone associated with the opaline chert, with crystals of different size and shape. Crossed nicols. (B) Dolomitic inclusions, mainly globular bodies with large dolomitic centres; these are common in the opaline chert (some are arrowed). Plane polarized light. (C, D, E, F, G and H) SEM photomicrographs. (C) A single rounded dolomite crystal. (D) Dolomitic spherules in the opaline chert. These are composed of clusters of coalesced rhombohedral dolomite subunits. Upper right: a single dolomite crystal can be seen (arrowed). (E) Close-up of the dolomite subunits; opal lepispheres growing between the crystals. The lepispheres are nucleated on fibres, possibly of sepiolite. (F). Spherule with a hole in the centre. (G) Spherule composed of dolomite crystals organized as radii. An argillaceous film coats the spherule. (H) Section of a fibrous spherule that was analysed by WDS (black rectangles). 

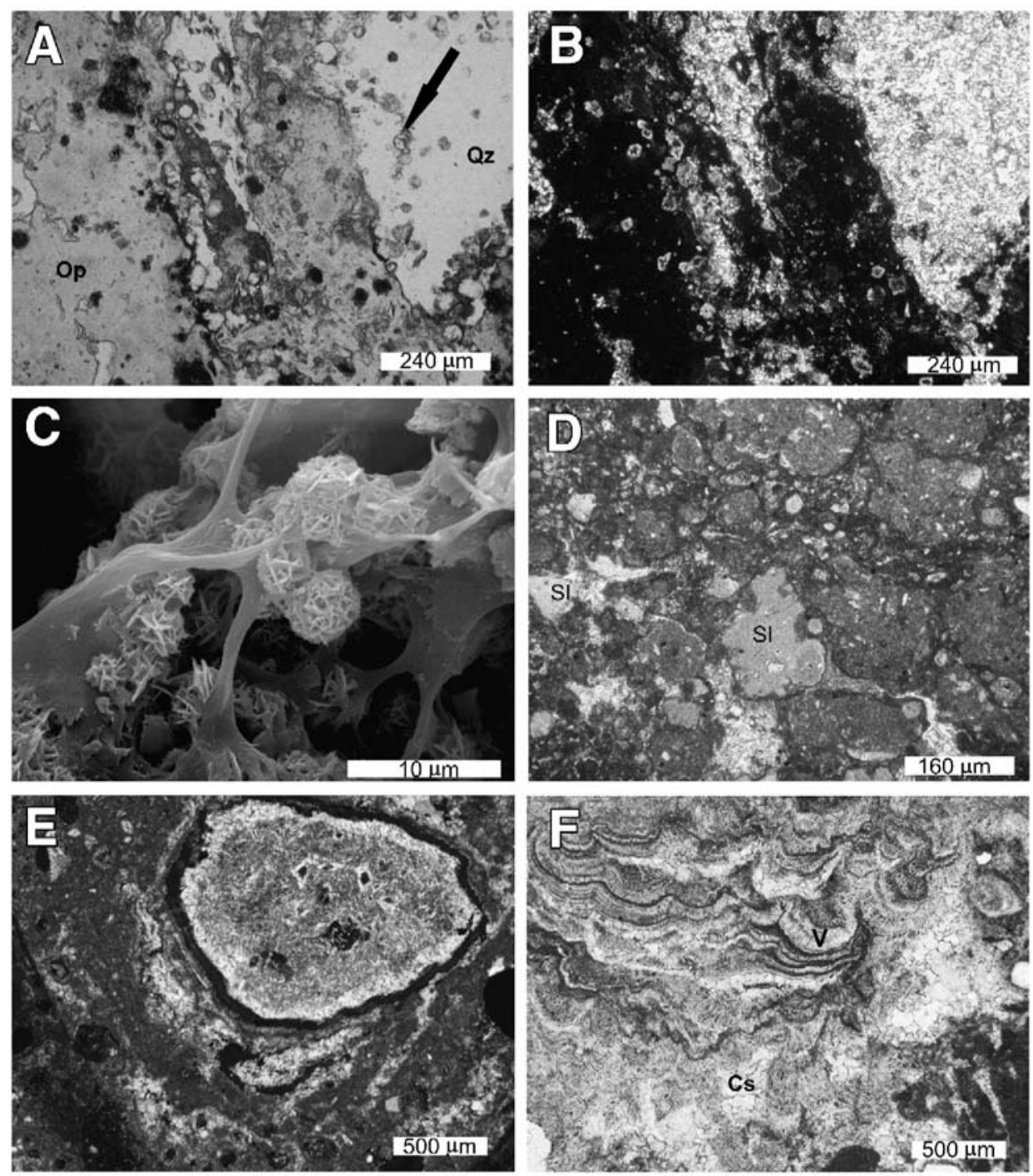

Fig. 7. PEL and UPC sections. (A) Isotropic opal (Op) aging to quartz (Qz). Several spherules and globular dolomite bodies are dispersed in the opaline and quartz areas (arrowed). Plane polarized light. PEL section. (B) Idem. Crossed nicols. (C) SEM picture of opal lepispheres growing in the voids; in some cases they nucleated on fibrous ribbons, probably of sepiolite. PEL section. (D) Silicified intraclasts (SI) show the same morphology and size than not silicified intraclasts, which are darker. Plane polarized light. UPC section. (E) Intraclasts replaced by quartz show alternating pendant silica and carbonate cements developed mostly on the undersides. Crossed nicols. UPC section (F) Microstalactitic vadose cements (V) in the outer part of a void and coated by calcite spar mosaics (Cs). UPC section. Crossed nicols.

The opaline cherts occur mostly at the top of both UPC profiles. In general, opal CT is the most common mineral, but quartz is also present. Microscopically two types of opal are distinguished: isotropic opal and opal with striated birefringence. Isotropic opal appears mostly in the lower and middle part of both profiles, especially where silicification occurs on limestones of low sepiolite content. In this case, opal is present as glaebules and intraclasts that reflect the morphology of the carbonate grains formed through grainification (Fig. 7D). Moreover, micrite relics and also organic micritic coatings are still preserved both in glaebules and intraclasts. In some cases, it is possible that the shape of the silica glaebules was not inherited from the carbonates but that they formed primarily in vadose/edaphic environments as glaebular silica accumulations (Nahon, 1991).

The upper parts of the two profiles are richer in sepiolite, and here the opal shows striated birefringence and a glaebular structure, although locally it has a brecciated structure inherited from the host rock.

Under the SEM, the isotropic opal shows no evidence of the prior presence of fibres, but some root 


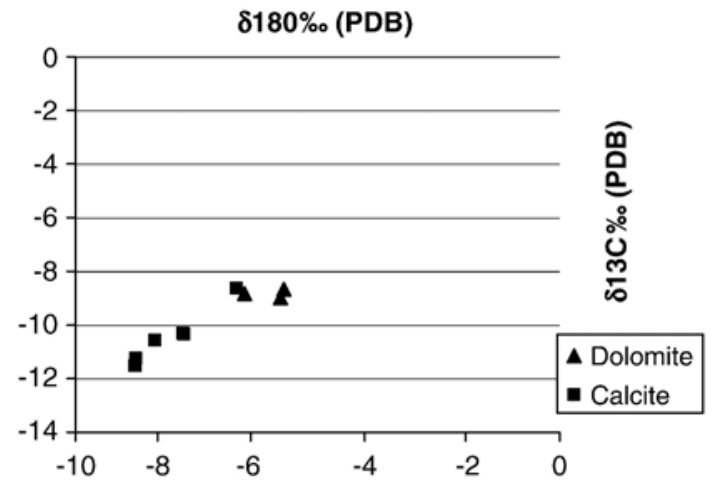

Fig. 8. Cross plot of the $\delta^{13} \mathrm{C}$ and $\delta^{18} \mathrm{O}$ values of the studied carbonates.

cavities and fungal filaments are preserved. Fibres only occur in the opal with striated birefringence. Quartz usually fills the cavities and forms irregular masses through ageing. Locally it replaces microfossils and plant debris. This quartz is mostly represented by microcrystalline quartz and length-fast chalcedony.
Length-slow chalcedony (quartzine) is present very locally in some organic structures and in aged areas. Some silicified intraclasts show calcite and quartz vadose cements followed by coarse calcite spar cement (Fig. 7E). Locally there are vadose microstalactite cements of calcite (Fig. 7F).

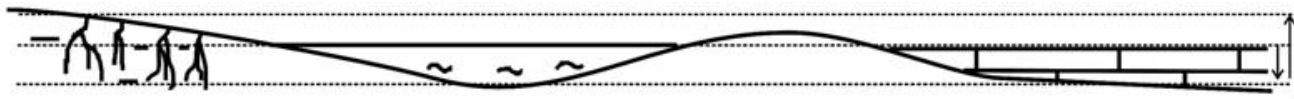

Distal alluvial fan

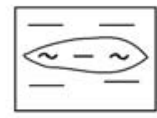

1. Deposition of line clastics (mainly smectities) and

formation of sepiolite

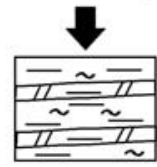

2. Formation of inmature carbonate soils

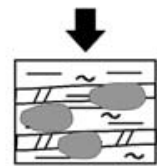

3. Silicification of sepiolite and carbonates (Vadose/Pheatic)

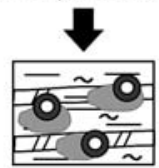

4. Dolomitization of carbonates sepiolite and opal
Isolated ponds

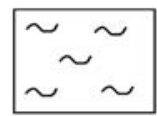

1. Sepiolite deposition

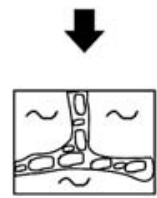

2. Palustrine exposure and desiccation

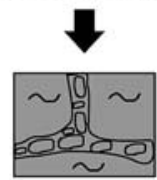

3. Silicification of sepiolite (Vadose/Pheatic)

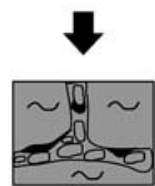

4. Vadose siliceous cements

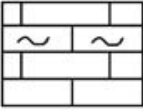

1. Palustrine carbonates and minor sepiolite deposition and exposure

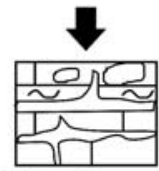

WT-2

2. Subaerial exposure

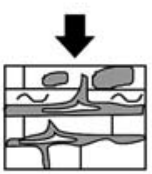

WT-3

3. Silicification of carbonates and sepiolite (Vadose/Pheatic)

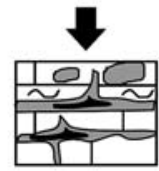

WT-4

4. Vadose carbonate cements in silicified beds

Fig. 9. Sketch showing the sequence of processes occurring in the study area. The main variations of the water table are also shown. 


\section{Stable isotopes}

Stable isotope analyses were performed only on samples from the UPC and PEL sections (Fig. 8) since, in the BER section, carbonate is only a minor rock component. Isotope analyses in the Paracuellos de Jarama area previously focused on palaeosols (Wright and Alonso-Zarza, 1992), dolomicrites (Calvo et al., 1995) and calcretes containing calcified root cells (Alonso-Zarza et al., 1998). These earlier results are clearly comparable to those obtained in the present study. The calcitic samples (UPC), which are mostly palustrine, show a good covariant trend indicating a closed lake system (Talbot, 1990). In addition, the initial primary geochemical signature of the meteoric waters is preserved (Alonso-Zarza, 2003). These waters mostly fed the shallow lake systems; some of the carbon they contain could have been supplied by soil organic matter (Wright and Alonso-Zarza, 1992). The slightly heavier values for the dolomitic samples (PEL profile) are explained by the isotopic fractionation involved in dolomite precipitation (Northrop and Clayton, 1966), but also by the more evolved waters that caused dolomitization.

\section{Discussion}

The mineralogy and textures of the studied deposits reveal the interplay of a number of sedimentary, pedogenic and phreatic diagenetic processes that operated in these distal alluvial areas and shallow lakes (Fig. 9).

\subsection{Sedimentation in distal fan areas}

In the distal areas of the arkosic fans of the Madrid Basin, mudstones and siltstones were deposited and high ground water tables enabled the formation of shallow water bodies in which carbonates and sepiolite formed (Calvo et al., 1996). The shallow water bodies were situated at the foot of the alluvial fans or in interfan areas. Moreover the stages or areas with very low sedimentation rates were favourable for the formation of soils (Alonso-Zarza et al., 1992). The general model for the Madrid Basin indicates a closed basin with a centripetal facies arrangement (Calvo et al., 1989), however the possibility of some wetlands fed by groundwater should be considered. This same type of situation has recently been described for the Loboi plain in Kenya, where the drainage of the Loboi River occurs via a swampy area that runs transversally to the alluvial fans (Ashley et al., 2004). Nowadays, in Loboi plain in Kenya, wetlands are formed in a semi-arid environment.
In some areas during a period of exceptionally heavy rainstorms, a river diversion took place and created a wetland that become a shallow freshwater lake with an extensive zone of wetland vegetation around its margins. The waters vary from fresh to alkaline, and have a salinity about twice that of the local streams. The lake has since stabilized and is recharged by ephemeral stream flow and shallow groundwater seepage (Ashley et al., 2004). The OKavongo fan can be illustrative, to show how a vegetated swamp area in a distal fan, under semi-arid climate, can propitiate the formation of calcretes and silcretes. Higher grounds on the flood plain form islands during the seasonal flood. Elevated tracts arise by displacement, subsurface crystallization of carbonate and silica, which is induced by trees that grow on the higher ground. The sedimentation on lower areas occurs by the combination of clastic material and precipitation of fine grained amorphous silica from the groundwater, induced by transpiration by aquatic grasses and sedges (McCarthy and Ellery, 1995).

Some characteristics of the carbonate levels (especially in the UPC section), such as the micrite composition, the intraclasts, the channels and planar void fillings, the root mats, the ostracods and charophytes, the associated fine levels of sepiolite and the small silica nodules of silica, are also seen along pan margins in Eastern Central Namibia (Mees, 2002). In both cases the sediments formed in very shallow and ephemeral water bodies. The main difference is the absence of diatoms in the UPC section; these are common in some deposits of the Namibian pan margins, in the Okavango Fan, and on the Loboi Plain.

\subsection{Soil forming processes}

Soil forming processes in these deposits contributed mostly to the disorganization of the primary deposits (host rock), but were not sufficiently intense to form well defined soil horizons. In the distal fan areas (PEL section), weakly developed soils formed on the grey mudstones, leading to the formation of thin carbonate laminae and small nodules due to root activity (AlonsoZarza, 1999) confirmed by alveolar septal structures and micritic filaments. Iluviation of clays also occurred, but very locally. In the pond and lacustrine environments (BER and UPC sections), pedogenic processes modified the initial homogeneity of the primary lacustrine lime mud and even of the sedimentary sepiolite, allowing the formation of textures characteristic of palustrine deposits (Freytet and Verrecchia, 2002; Alonso-Zarza, 2003; Huerta and Armenteros, 2005). The formation of sepiolite in soil profiles is discussed below. 


\subsection{Formation of sepiolite}

Sepiolite occurs in two situations in the study area: 1) as individual beds of very pure sepiolite (the BER section and thin levels interlayered with carbonates in the lower UPC profile) and 2) mixed with other deposits such as smectites and carbonates (PEL and UPC sections). The genesis of the sepiolite differs in each.

In the first case (the BER section) the size of the sepiolite deposits and their features, very similar to those described for palustrine carbonates, clearly indicate sepiolite to have been the primary precipitate within free water bodies, either ponds or shallow lakes. Lacustrine sepiolites are commonly referred to in the literature (Doval et al., 1985; Ordoñez et al., 1991; Tateo et al., 2000). In most cases sepiolite forms in arid to semi-arid climates in closed terrestrial basins where it precipitates directly from $\mathrm{Mg}$ and $\mathrm{Si}$-enriched solutions with low $\mathrm{Al}$ concentrations (Starkey and Blackmon, 1984; Mayayo et al., 1998). The presence of thin sepiolite levels in the upper part of the shallow carbonate beds (UPC) suggests that sepiolite formation was favoured towards the end of carbonate sedimentation, when the lake water had a higher $\mathrm{Mg}$ concentration because of the previous precipitation of calcium carbonates in the presence of silica.

In the second case (PEL section and small amounts of sepiolite in the UPC section), sepiolite could have formed by the transformation of previous illites or smectites in a vadose alkaline environment (Calvo et al., 1986) or by direct precipitation within interstitial solutions. The process may also have been favoured by the initial accumulation of carbonates within the soil horizons. This would have increased the $\mathrm{Mg} / \mathrm{Ca}$ ratio of the interstitial solutions favouring sepiolite precipitation (Watts, 1980). The presence of sepiolite within calcrete profiles is very commonly cited in arid-semi-arid environments (Verrechia and Le Coustumer, 1996). Some authors also described that sepiolite can nucleate on opals in soils (Blank and Fosberg, 1991).

\subsection{Silicification}

\subsubsection{The mechanism of replacement}

The sepiolites are silicified in the three study settings, more intensely so in the case of the sepiolite pond deposits (BER section). The replacement of sepiolite by opal was pseudomorphic since the macrostructure and fibrous microstructure of the sepiolite is preserved. In the first step, silicification resulted in an atypical, porous opal that in thin section showed striated birefringence, as consequence of the sepiolite fibrous structure. When the silicification progressed the fibres became joined and cemented together to form blades. The result is a compact structure in which the inherited striated birefringence can still be observed. In a later phase, compact and isotropic opal may have formed due to the loss of the inherited sepiolite structure.

The pseudomorphic replacement of sepiolite by opal has not been studied in detail, although it has been documented in some opals formed by the silicification of palygorskite and sepiolite (Fritsch et al., 2004). In some cases it is difficult to distinguish $\mathrm{Mg}$ clay fibres from their imprints on the opal. The fact that in the Tagus Basin large amounts of opals form on sepiolites (Bustillo, 1976) suggests that these clays and their structure help them to nucleate. The preference of silica for sepiolite is due to the fact that both can exit under similar geochemical conditions. In lacustrine settings and soils in arid environments, sepiolite and opal can coexist, the precipitation of one or the other controlled by small changes in silica and $\mathrm{Mg}$ activities and $\mathrm{pH}$ (Millot, 1970). Moreover, the high absorption capacity of sepiolite and its fibrous and porous microstructure favour the accumulation and permanence of vadose and phreatic water and the fixation of silica on the fibres.

The silicification of limestone is seen mainly in the UPC section, where it produces isotropic opal. The silicification process reproduces the textures of the grains, peloids and intraclasts. The replacement of limestones by silica is very common, driven mainly by variations in $\mathrm{pH}$. $\mathrm{pH}$ values $<9$ favour the dissolution of calcite and the precipitation of silica, whereas higher values induce the opposite, giving place to the calcitization of silcretes (Nash and Shaw, 1998). In surface environments, such as the shallow lakes and soils, these variations are very common. Nonetheless, McCarthy and Ellery (1995) indicate that $\mathrm{pH}$ is not as important for silicification as an increase in salinity due the loss of water by plant activity.

\subsubsection{Silicification environments and source of silica}

In semi-arid, near-surface environments, the characterization of vadose and phreatic zones is problematic because of the variations in the water table that give place to complex carbonate textures (Huerta and Armenteros, 2005). In addition, perched water tables may temporally form (Salve and Tokunaga, 2002).

According to Thiry (1997), pedogenic silicifications show typical soil structures related to infiltration and downward percolation of water, and this obliterates the structures of the parent material. Groundwater silicification, however, largely retains the primary structure of the host material. In the BER section, the opals perfectly 
reproduce the structure of the sepiolitic host rock (Figs. 4 and 5), indicating a phreatic environment. However, textures reflecting transformations in vadose environments are also present, such as grainification, internal sedimentation and cracks (Fig. 5B and C) that indicate a vadose phase. The overlapping of groundwater and vadose silicification has been described in the Sepúlveda-Ayllón closed basin (Armenteros et al., 1995) and in the nearby silcretes of the Madrid Basin (Bustillo and Bustillo, 2000). Aging processes leading to the formation of micro to cryptocrystalline quartz from opal also occurred in a later vadose environment.

In the distal alluvial fan sediments (PEL section) the initial host rock is not preserved, and even after silicification a dolomitization process erased most of the primary features. It is therefore difficult to know whether the silicification took place in a phreatic or vadose environment.

In the UPC section, the perfect conservation of the palustrine structures and textures of the shallow carbonates in the opaline cherts also indicates groundwater silicification. Vadose processes can also exist and lead to the formation of silica glaebules not inherited from the palustrine limestones. Along the margins of saline pans in Namibia, Mees (2002) described that initial unconsolidated deposits were affected by early silicification and carbonate precipitation shortly after the deposits became exposed under evaporative conditions. Plants can play a role in the silicification process in sedimentary environments; such is the case in the Okavango delta, where fine grained amorphous silica precipitates from the groundwater induced by the transpiration of aquatic grasses and sedges (McCarthy and Ellery, 1995). In the present study area, later groundwater quartz cementation is observed. This process was a consequence of the elevation of the water table under more humid conditions. Carbonate stalactitic cements after the quartz cements (Fig. 7F) indicate a later vadose environment.

In none of the studied sections were biogenic sources of silica evident; phytoliths were scarce and there were no diatoms. Thus, most of the silica present probably has an inorganic origin. The formation of opal needs a relatively silica-rich (about $100 \mathrm{ppm}$ ) groundwater (Heaney and Banfield, 1993). Some of this silica came from the same host rock - either sepiolite itself or a material rich in this mineral.

\subsection{Dolomitization}

Most of the dolomites in the Madrid Basin are fine dolomicrites (Calvo et al., 1995) and are interpreted as the result of early dolomitization of marginal lake areas due to evaporation and subsequent increase in the $\mathrm{Mg}$ / Ca ratio. Spheroidal dolomites (rounded crystals, spherules and globular bodies) occur only very locally in the studied profiles, but their texture renders them of some interest. These dolomites are associated with the dolomicrites and opaline cherts of distal fan areas. Some thin sections show isolated dolomite crystals superimposed on different opaline structures (glaebules, striated birefringence, aged layers, etc.) indicating that the dolomite nucleates on the opaline chert contain sepiolite relics. These areas enriched in $\mathrm{Mg}$ could be favourable sites for dolomite nucleation (Nielsen et al., 1997). In general the composition/microstructure of the opal phases may favour the neoformation of carbonates in specific sites, as observed in other chert deposits (Bustillo and RuizOrtiz, 1987; Misik, 1993). The fact that some dolomites are spheroidal is not easily explained. Arvidson and Mackenzie (1999) argue that their growth morphology depends on the saturation of the solution, a high saturation favouring fast and continuous growth resulting in spheroidal instead of rhombohedral morphology (as spheroids have more surface area). In the present case, the microporous structure of the opal, which contains water, could offer good nucleation sites. It is not completely clear whether the initial precipitate was dolomite, protodolomite or hydrous calcium magnesium carbonates. Kelleher and Redfern (2002) have shown experimentally that a hydrous disordered phase (protodolomite) forms relatively quickly ( 23 days) at $80{ }^{\circ} \mathrm{C}$ from molar solutions of $\mathrm{Ca}\left(\mathrm{NO}_{3}\right)_{2}, \mathrm{MgSO}_{4}$ and $\mathrm{Na}_{2} \mathrm{CO}_{3}$. The protodolomite showed spheroidal morphology with darker nuclei and a lighter cortex. The sulphate it contains seems to favour the nucleation rate and slows down the rate of crystal growth, leading to the formation of a poorly ordered $\mathrm{Ca}$ and water (2-3\%)rich phase. This phase has lower kinetic barriers than stoichiometric dolomite, but it can be unstable during early diagenesis, passing to dolomite.

A final aspect to consider is the influence of living organisms, especially bacteria, on dolomite formation. The present dolomite crystals have many features of dolomites formed under bacterial influence, such as spheroidal morphology, the dumbbell organization of some crystals, hollow nuclei, and the fact that there was no previous carbonate phase (Cavagna et al., 1999; Pedone and Dickson, 2000). However, similar dolomites have formed without bacterial influence, as in Upper Cretaceous/Lower Triassic of Egypt (Wanas, 2002). Here, two types of spheroidal dolomites directly precipitated from waters with different salinities and with no precursor carbonate phase. Further studies are required 
to confirm the influence of bacteria in the formation of the spheroidal dolomites of the Madrid Basin.

\subsection{Diagenetic sequences}

Despite the textural and mineralogical differences observed in the different profiles, the overall pedogenic and diagenetic processes followed a pattern governed by the position of the water table. Fig. 9 shows the general change in the level of the groundwater which consists of four main stages:

- Stage 1 indicates the position of the water table during sedimentation in distal fan, lakes and ponds (WT-1).

- During stage II the lowering of the water table led to the formation of soils in the distal alluvial fan areas, and to the exposure of the lacustrine sediments, including both sepiolite and carbonates.

- In Stage III the water table rose to reach WT-3. This is related to the aggrading of the basin. Rather than just one straightforward rise many intermediate positions must have existed, and even some falls. The result is an interplay between the vadose and phreatic processes, leading to the main stages of silicification in the three areas.

- A later lowering of the water table, to reach position WT-4, accounted for the development of the vadose processes responsible for the dolomitization and precipitation of siliceous and carbonate cements.

\section{Conclusions}

1. During the Aragonian, the alluvial fan deposits, shallow lakes and ponds in the Paracuellos area of the Madrid Basin, were subject to periodic changes in subaerial exposure and inundations that produced changes in groundwater levels. The interplay between vadose and phreatic environments led to important and successive transformations such as pedogenic modifications, dolomitization and silicification.

2. The alluvial fan deposits (PEL section) show the most complex sequence of processes. Initially weak soil-forming process disorganized the primary mudstones and siltstones and formed small carbonate accumulations, mainly due to the activity of roots. Later silicification formed lenticular opaline levels. Optical features of the opals, such as the striated birefringence and the microfibrous structure, suggest that these opals resulted from the silicification of sepiolite. Thus, in the distal alluvial fan deposits, sepiolite was preferentially silicified leading to silcrete development. Dolomitization occurred after silicification as shown by the dolomite crystals superimposed on the opal. The microporous structure of the opal (which contains water) could provide favourable nucleation sites for the dolomite. The initial silicification of sepiolite produced the release of $\mathrm{Mg}$, which might be the source of the dolomitization. Spheroidal dolomite may have formed in relation to bacterial activity.

3. In some ponds situated at the foot of the alluvial fans or in the interfan areas, sepiolite precipitated within free water bodies (BER section). The pedogenic processes were intense, leading to the formation of textures and structures characteristic of palustrine deposits. Later, the intense silicification of the palustrine sepiolite produced lenticular opaline levels. The total reproduction of the structure of the sepiolitic host rock within the opal indicates a phreatic environment, but some textures such as grainification and internal sedimentation etc., also indicate a later vadose phase. The aging of the opal to quartz probably took place in the vadose environment.

4. In the shallow lakes associated with the alluvial fans (UPC section sections), palustrine carbonates and sepiolite were deposited. The carbonates were partially affected by vadose and groundwater silicifications, the thin levels of sepiolite being preferentially silicified. Opaline silcretes formed and generally reproduced the structure of the carbonate and sepiolite host rocks (groundwater silicification), but sometimes they show vadose textures. The aging of the opal to quartz probably occurred in a later vadose environment. The presence of calcite vadose cements suggests a later phase of carbonate precipitation after silicification.

5. In all the studied environments, the sepiolite deposits were preferentially silicified. This was a pseudomorphic replacement in which the shape of the sepiolite fibres was initially conserved, although finally the fibres joined and became cemented together to form opaline blades. Sepiolites are preferentially silicified because their fibrous structure and high absorption capacity help to retain the interstitial fluids. Moreover, sepiolite and opal are stable under similar geochemical conditions in arid environments, the precipitation of one or the other controlled by small changes in silica and $\mathrm{Mg}$ activities and $\mathrm{pH}$. The dissolution of sepiolite causes an increase of silica in the interstitial fluids favouring silicification. The replacement of limestones by silica is very common and normally driven by variations in the $\mathrm{pH}$ (although always around 9), as well as by variations in the salinity of the groundwater. 
In surface environments such as shallow lakes and soils, these variations are very common.

\section{Acknowledgements}

The research was supported by projects CLG 200505953-01 and -02 from the Ministerio de Educación y Ciencia. This paper benefited greatly from the careful revision by V.P. Wright and editorial assistance of Adrian Burton.

\section{References}

Alonso, A.M., Calvo, J.P, García del Cura, M.A., 1986. Sedimentología y Petrología de los abanicos aluviales y facies adyacentes en el Neógeno de Paracuellos de Jarama (Madrid). Estudios Geológicos 42, 79-101.

Alonso-Zarza, A.M., 1999. Initial stages of laminar calcrete formation by roots: examples from the Neogene of central Spain. Sedimentary Geology 126, 177-191.

Alonso-Zarza, A.M., 2003. Palaeoenvironmental significance of palustrine carbonates and calcretes in the geological record. Earth Sciences Reviews 60, 261-298.

Alonso-Zarza, A.M., Calvo, J.P., García del Cura, M.A., 1992. Palustrine sedimentation and associated features - grainification and pseudo-microkarst - in the Middle Miocene (Intermediate Unit) of the Madrid Basin, Spain. Sedimentary Geology 76, 43-61.

Alonso-Zarza, A.M., Sanz, M.E., Calvo, J.P., Estévez, P., 1998. Calcified root cells in Miocene pedogenic carbonates of the Madrid Basin: evidence for the origin of Microcodium. Sedimentary Geology 116, 81-97.

Alonso-Zarza, A.M., Calvo, J.P., Silva, P.G., Torres, T., 2004. Cuenca del Tajo. In: Vera, J.A. (Ed.), Geología de España. SGE-IGME, Madrid, pp. 556-563.

Armenteros, I., Bustillo, Ma ${ }^{\mathrm{a}}$ A., Blanco, J.A., 1995. Pedogenic and groundwater processes in a closed Miocene basin (northern Spain). Sedimentary Geology 99, 17-36.

Arvidson, R.S., Mackenzie, F.T., 1999. The dolomite problem: control of estoy en precipitation kinetics by temperature and saturation state. American Journal of Science 299, 257-288.

Ashley, G.M., Maitima Mworia, J., Muasya, A.M., Owens, R.B., Driese, S.G., Hover, V.C., Renaut, R.W., Goman, M.F., Mathai, S., Blatt, S.H., 2004. Sedimentation and recent history of a freshwater wetland in a semi-arid environment: Loboi Swamp, Kenya, East Africa. Sedimentology 51, 1301-1323.

Blank, R.R., Fosberg, M.A., 1991. Duripans of the Owyhee plateau region of Idago: genesis of opal and sepiolite. Soil Science 152, 116-133.

Bustillo, M.A., 1976. Estudio petrológico de las rocas silíceas miocenas de la Cuenca del Tajo. Estudios Geológicos 32, 451-497.

Bustillo, M.A., 1982. Ageing features in organic continental opals. Estudios Geológicos 38, 335-344.

Bustillo, M.A., Bustillo, M., 2000. Miocene silcretes in argillaceous playa deposits, Madrid Basin, Spain: petrological and geochemical features. Sedimentology 47, 1023-1039.

Bustillo, M.A., Ruiz-Ortiz, P.A., 1987. Chert occurrences in carbonate turbidites: examples from the Upper Jurassic of the Betic Mountains (southern Spain). Sedimentology 34, 611-621.

Calvo, J.P., Alonso-Zarza, A.M., García del Cura, M.A., 1986. Depositional controls on sepiolite occurrence in Paracuellos de Jarama, Madrid Basin, Geogaceta 1, 25-28.
Calvo, J.P., Alonso-Zarza, A.M., García del Cura, M.A., 1989. Models of marginal lacustrine sedimentation in response to varied source areas in the Madrid Basin (Central Spain). Palaeogeography, Palaeoclimatology, Palaeoecology 70, 199-214.

Calvo, J.P., Jones, B.F., Bustillo, M., Fort, R., Alonso-Zarza, A.M., Kendall, C., 1995. Sedimentology and geochemistry of carbonates from lacustrine sequences in the Madrid Basin, Central Spain. Chemical Geology 123, 173-191.

Calvo, J.P., Alonso-Zarza, A.M., García del Cura, M.A., Ordóñez, S., Rodríguez-Aranda, J.P., Sanz Montero, E., 1996. Sedimentary evolution of lake systems through the Miocene of the Madrid Basin: paleoclimatic and paleohydrological constraints. In: Friend, P.F., Dabrío (Eds.), Tertiary Basins of Spain. Cambridge University Press, Cambridge, pp. 264-269.

Cavagna, S., Clari, P., Martaire, L., 1999. The role of bacteria in the formation of cold seep carbonates: geological evidences from Monferrato (Tertiary, NW Italy). Sedimentary Geology 126, 253-270.

Doval, M., Domínguez Díaz, M.C., Brell, J.M., García Romero, E., 1985. Mineralogía y Sedimentología de las facies distales del borde Norte de la Cuenca del Tajo. Boletín Sociedad Española de Mineralogía 257-269.

Freytet, P., Plaziat, J.C., 1982. Continental carbonate sedimentation and pedogenesis - Late Cretaceous and Early Tertiary of southern France. Contributions to Sedimentology 12 (213 pp.).

Freytet, P., Verrecchia, E.P., 2002. Lacustrine and palustrine carbonate petrography: an overview. Journal of Paleolimnology 27, 221-237.

Fritsch, E., Gaillou, E., Ostroumov, M., Rondeau, B., Devouard, B., Barreau, A., 2004. Relationship between nanostructure and optical absorption in fibrous pink opals from Mexico and Peru. European Journal of Mineralogy 16, 743-751.

Gehring, A.U., Keller, P., Frey, B., Luster, J., 1995. The occurrence of spherical morphology as evidence for changing conditions during the genesis of sepiolite deposits. Clay Minerals 30, 83-86.

Heaney, P.J., Banfield, J., 1993. Structure and chemistry of silica, metal oxides, and phosphates. In: Guthrie, G.D., Mossman, B.T. (Eds.), Health Effects of Mineral Dusts Reviews in Mineralogy, vol. 28, pp. 185-233.

Huerta, P., Armenteros, I., 2005. Calcrete and palustrine assemblages on a distal alluvial-floodplain: a response to local subsidence (Miocene of the Duero basin, Spain). Sedimentary Geology 177, 253-270.

Junco, F., Calvo, J.P., 1984. Cuenca de Madrid. Geología de España. Libro Jubilar J.M. Ríos, vol. 2. IGME, pp. 534-543.

Kelleher, I.J., Redfern, S.A.T., 2002. Hydrous calcium magnesium carbonate, a possible precursor to the formation of sedimentary dolomite. Molecular Simulation 28, 557-572.

Mayayo, M.J., Torres-Ruiz, J., González-López, J.M., López-Galindo, A., Bauluz, G., 1998. Mineralogical and chemical characterization of the sepiolite/Mg-smectite deposits at Mara (Calatayud Basin, Spain). European Journal Mineralogy 10, 367-383.

Mazullo, S.J., Birdwell, B.A., 1989. Syngenetic formation of grainstones and pisolites from fenestral carbonates in peritidal settings. Journal of Sedimentary Petrology 59, 605-611.

McCarthy, T.S., Ellery, W.N., 1995. Sedimentation on the distal reaches of the Okavango Fan, Botswana, and its bearing on calcrete and silcrete (ganister) formation. Journal of sedimentary research. Section A, Sedimentary petrology and processes 65, 77-90.

Mees, F., 2002. The nature of calcareous deposits along pan margins in Eastern Central Namibia. Earth Surface Proceedings Landforms 27, 719-735. 
Millot, G., 1970. Geology of Clays. Springer-Verlag, New York. 499 pp.

Misik, M., 1993. Carbonate rhombohedra in nodular cherts: Mesozoic of the West Carpathians. Journal of Sedimentary Petrology 63, 275-281.

Nahon, D.B., 1991. Introduction to the Petrology of Soils and Chemical Weathering. John Wiley and Sons, Inc, New York. 313 pp.

Nash, D.J., Shaw, P.A., 1998. Silica and carbonate relationships in silcrete-calcrete intergrade duricrusts from the Kalahari of Bostswana and Namibia. Journal of African Earth Sciences 27, 11-25.

Nielsen, P., Swennen, R., Dickson, J.A.D., Fallick, Q.E., Keppens, E., 1997. Spheroidal dolomites in a Visean karst system-bacterial induced origin. Sedimentology 44, 177-195.

Northrop, D.A., Clayton, R.N., 1966. Oxygen isotope fractionation in systems containing dolomite. Journal of Geology 74, 174-196.

Ordoñez, S., Calvo, J.P., García del Cura, M.A., Alonso-Zarza, A.M., Hoyos, M., 1991. Sedimentology of sodium sulphate deposits and special clays from the Tertiary Madrid Basin (Spain). In: Anadón, P., Cabrera, L., Kelts, K. (Eds.), Lacustrine Facies Analysis. Special Publication of the International Association of Sedimentologists, vol. 13, pp. 39-55.

Pedone, V.A., Dickson, J.A.D., 2000. Replacement of aragonite by quasi rhombohedral dolomite in a Late Pleistocene tufa mound, Great Salt Lake, Utah, USA. Journal Sedimentary Research 70, $1152-1159$.

Salve, R., Tokunaga, T.K., 2002. Seepage response along an alluvial valley in a semiarid catchment in north-central California. Hydrological Processes 16, 65-86.

Starkey, M.C., Blackmon, P.D., 1984. Sepiolite in Pleistocene Lake Tecopa, Inyo County, California. In: Singer, A., Galán, E. (Eds.), Palygorskite-Sepiolite Occurrence, Genesis and Uses. Developments in Sedimentology, vol. 37. Elsevier, Amsterdam, pp. 137-148.
Summerfield, M.A., 1983. Silcrete. In: Goudie, A.S., Pye, K., Guthrie, G.D., Mossman, B.T. (Eds.), Chemical Sediments and Geomorphology. Academic Press, London, pp. 59-61.

Talbot, M.R., 1990. A review of the palaeohydrological interpretation of carbon and oxygen isotopic ratios in primary lacustrine carbonates. Chemical Geology 80, 261-279.

Tateo, F., Sabbanini, R., Morandi, N., 2000. Palygorskite and sepiolite occurrence in Pliocene lake deposits along the River Nile: evidence of an arid climate. Journal of African Earth Sciences 31, 633-645.

Thiry, M., 1997. Continental silicifications: a review (1997). In: Paquet, H., Clauer, N. (Eds.), Soils and Sediments. Mineralogy and Geochemistry. Springer, pp. 191-221.

Verrechia, E.P., Le Coustumer, M.N., 1996. Occurrence and genesis of palygorskite and associated clay minerals in a Pleistocene calcrete complex, Sde Boquer, Negev Desert, Israel. Clay Minerals 31, 183-202.

Wanas, H.A., 2002. Petrography, geochemistry and primary origin of spheroidal dolomite from the Upper Cretaceous/Lower Tertiary Maghra El-Bahary Formation at Gabal Ataqa, Northwest Gulf of Suez, Egypt. Sedimentary Geology 151, 211-224.

Watts, N.L., 1980. Quaternary laminar calcretes from the Kalahari (southern Africa): mineralogy, genesis and diagenesis. Sedimentology 27, 661-686.

Wright, V.P., 1986. The role of fungal biomineralization in the formation of early Carboniferous soil fabrics. Sedimentology 33, 831-838.

Wright, V.P., Alonso-Zarza, A.M., 1992. Significado de la composición isotópica $\left(\delta^{13} \mathrm{C}\right.$ y $\left.\delta^{18} \mathrm{O}\right)$ en paleosuelos carbonatados. Mioceno de la Cuenca de Madrid. Geogaceta 11, 61-63.

Wright, V.P., Platt, N.H., Wimbledon, W.A., 1988. Biogenic laminar calcretes: evidence of calcified root-mat horizons in palaeosols. Sedimentology 35, 603-620. 